\title{
A case study on the determination of unused capacity using time driven activity-based costing for electronic component
}

\author{
N.F. Zamrud ${ }^{1}$, S.N.A.M. Zaini ${ }^{1 *}$ and M.Y. Abu ${ }^{1}$ \\ ${ }^{1}$ Faculty of Manufacturing and Mechatronic Engineering Technology, Universiti Malaysia Pahang, 26600, \\ Pekan, Pahang, Malaysia \\ *Email: areena5582@gmail.com
}

\begin{abstract}
Nowadays, demand for magnetic components are increasing from customer to support technological needs. It is important for the producer to incorporate an accurate cost estimation to decide the best price to gain better profits. However, actual costing structure is ignored the potential of time equation and capacity cost rate to measure the unused capacity from the resources allotment. The objective of this work is to determine the unused capacity in term of duration and cost in the manufacturing of electronic component using time-driven activity-based costing (TDABC). The method was developed using seven stages which are resources group identification, estimate cost of resources supplied, practical capacity estimation, capacity cost rates calculation, time equation development, determine time estimates for each sub-activity and estimate capacity cost required. As a result, in sub-activity- 1 of the wire are winded using CNC machine, the unused time was 246,156.29 minutes which needs to be re-examined so that maximum time for productivity can be achieved and the unused capacity of cost was MYR 623,804.93 which conveys the message of wastage at the workstation. In sub-activity-3 of pick up the coils from flattening station, the amount of unused time and cost was 596,400 minutes and MYR -7,006,252.43 respectively. The negative value demonstrated that the operators are overworked than normal time allocation. In sub-activity 9 of arrange core on the magnetic strip, the amount of unused time was $-596,400$ minutes and MYR -7,006,252.43 for unused cost probably the job scopes were taking more time than it should to be completed. Therefore, by applying the TDABC method, the capacity utilization and time efficiency can be clearly viewed.
\end{abstract}

Indexed Terms- Unused capacity, Time equation, Capacity cost rate, Electronic component

\section{INTRODUCTION}

Financial accuracy is an extremely desired type of costing sustainment in competitive environment. It is known that many financial failures occur as a result of the timing activity inaccuracy. An effective way to increase the accuracy to costing sustainment is by introducing time equation on the activities which may also strengthen the operating baseline [1-2]. Traditional activity-based costing (ABC) is a costing method originally developed in the 1980s in response to the shortcomings of traditional costing system method in an era of rapidly increasing product complexity and diversification [3]. The method accumulates indirect costs for each activity and then assigns the costs of the activities to the product causing that activity [4]. The method provides more accurate cost information for competitive price strategy [5], provides relevant information for the decision-making process in various domains [6] and allows scrutiny of the complete map of activities [7]. Therefore, it can effectively improve the costing sustainment on electric and electronic industry. However, it was not universally accepted because the produced model theoretically incorrect when it ignored the potential for unused capacity which will be beneficial for forecasting. [8]. Time-driven activity-based costing (TDABC) which introduced by Kaplan and Anderson may overcome the limitation of traditional ABC by systematically enhancing resources utilization by defining the opportunities of cost reduction without compromising outcome [9]. There is a possibility that the time equation on the electric and electronic industry activities can be introduced in a better accuracy if the variations can be completely identified. Hence, its financial 
accuracy can be further improved. Therefore, TDABC can be conveniently applied to introduce the unused capacity of allocated time and expenses to financial accuracy by introducing the time equation on the industry activities. The objective of this work is to determine the unused capacity in term of duration and cost in the manufacturing of electronic component using TDABC. This work is expected to offer contributions to the current literature by providing an additional evidence and information on the impact of new costing structure to the electrical and electronic production industry in Malaysia. While most of the previous studies were conducted in different sectors and countries.

The failure due to financial accuracy depends on many factors and very often it develops from particular structure of costing. ABC methodology is known to induce beneficial activity-oriented accounting on the product diversification which may improve the accuracy especially when the manufacturing overhead is uncertainty [10]. There are numerous reports on the effects of traditional $\mathrm{ABC}$ on the costing sustainment as reported by [11]. [12] identified the critical and non-critical variables during remanufacturing process using Mahalanobis-Taguchi System and simultaneously estimate the cost using ABC Costing method. The author found that, the cost per unit of remanufactured crankshaft of MAN engine model with 5 critical crankpins was MYR609.50 while Detroit engine model with 4 critical crankpins was MYR1254.80. In work by [4], the effect of crucial cost driver in ABC successfully allowed the development of more precise and targeted recommendations for management action. In autologous stem cell transplantation in multiple myeloma, the potential cost savings observed in traditional $\mathrm{ABC}$ could be allocated to help cover the costs of new drugs to treat hematologic malignancies [7]. [13] confirmed that $\mathrm{ABC}$ is believed to be a cure for the shortcomings of traditional costing system such as production that is too late, too aggregated and too distorted to be relevant for managers' planning and control decisions. However, TDABC may overcome the limitation of conventional $\mathrm{ABC}$ by systematically enhancing resources utilization by defining the opportunities of cost reduction without compromising outcome. The TDABC provides costs of activities with base in consume of time per activities [14]. It has been developed from the traditional ABC method which requires significant processing in data collection and cost allocation [15]. TDABC simplifies the complex formulations for $\mathrm{ABC}$ especially when there is any additional activity to be taken into account, the time equation can be easily extended [16]. In addition, TDABC is a bottom-up method that measures costs by calculating each resource's costs and the period each resource is used over the entire treatment cycle for each operation involved. This gives better and perhaps more straightforward estimates of the costs for treatment suppliers [17]. This costing method also is commonly used in manufacturing and other service industries to assign costs accurately [18] because it provides a granular view of costs which directly reflect resource use and duration, thus providing actionable cost data to improve particular processes [19]. According to [17], TDABC included the creation of process maps which illustrated the phases of each procedure component including workers, appliances and consumer goods involved in care. Estimation of the time required by each staff member and equipment by interviewing patient care, estimating operational costs, machinery, and supplies based on salary data, acquisition of equipment, and direct discussion to administration of medical center to assess the costs of services. It also estimates the capacity cost rate (CCR) for each member of staff and item of equipment by dividing the overall cost of patient care and any additional expenses of consumable with practical capacity. Obviously, TDABC approach overcame traditional ABC difficulties and had some advantages. The advantage over $\mathrm{ABC}$ is it simplifies the costing process and eliminates expensive processes of specialized processes for gathering data on resource costing and activities until it is focused at the target of expenses [14]. According to [20], TDABC offers the drivers of these costs with both precise measurements of the care cycle costs and greater transparency. TDABC may quantify true patient care costs and defined procedures, the quality of which can be enhanced without impacting the outcomes [21], able to deal with variability of industrial process [1], helped cost systems effectively and solve the current cost accounting problem [18], detailed benchmark calculations were provided for cost-benefit comparison and further optimization [22], revealed cost reduction and quality improvements [23] and able to discover technique cost effectiveness [24]. Moreover, TDABC has provided useful knowledge on process complexity and the utilization of resources [25], attributed unused resources and provided 
significant information on idle capacities [16] and given a complete and clear description of all surgical and recovery expenses [20]. In the existing system of the company, actual costing structure is ignored the potential of time equation and capacity cost rate to measure the unused capacity from the resources allotment. The objective of this work is to determine the unused capacity in term of duration and cost in the manufacturing of electronic component using TDABC.

\section{METHODOLOGY}

This work consists of three phases as shown in Figure 1. Phase 1 consists of identification of process and development of process mapping in the automotive manufacturing company. The objective is to find the appropriate scope to focus for detail analysis. Once the scope is identified, phase 2 is very important to develop the capacity cost rate. It consists of collection of data, direct and indirect cost i.e. Working hour, salary rate and historical data. During phase 3, the collected data is processed and analyzed to identify the unused capacity with respect to the duration and cost.

Phase 1

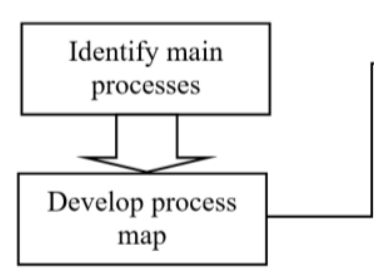

Phase 2

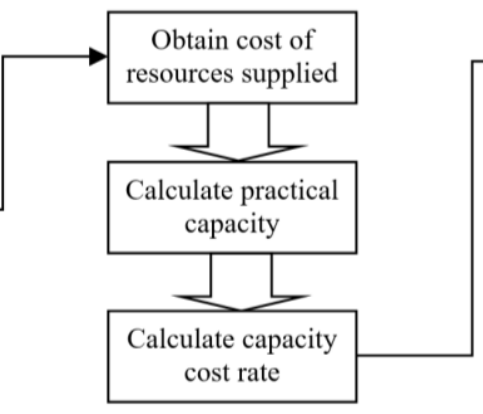

Phase 3

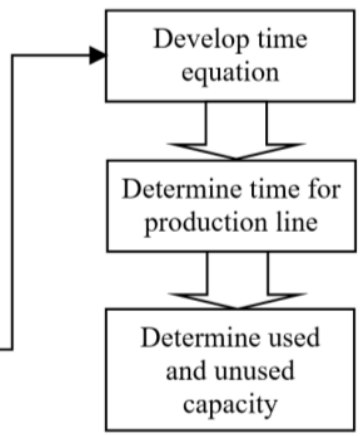

Figure 1: A flow chart of research methodology

Phase 1:

1. Identifying main processes in production line and defining focus of study.

2. Develop a process map associated with production incorporated with capacity supplying resources including personnel, facilities, equipment and consumables.

Phase 2:

1. Obtain the direct cost (i.e. salary and maintenance) to determine the cost of capacity supplied.

2. Determine time (minutes) required for productive work in a year without non-value activities to estimate the practical capacity of supplied resources.

3. Develop capacity cost rate for the production line.

Phase 3:

1. Develop time equation to represents the basic time required for each activity with the incremental time associated with each variation that can occur.

2. Multiply the capacity cost rate with the time equation to determine the cost of a resource being used.

3. Determine used an un-used capacity in production line. 


\section{RESULT AND DISCUSSION}

This study using TDABC as a costing system to determine unused capacity on a magnetic inductor process production in electrical and electronic industry. By implementing TDABC, it appraises the role of capacity cost rate and time equation which eventually leads capacity utilization information that is definitely useful for forecasting in the future. The endorsement company are experienced in manufacturing magnetics products with current range of transformers, inductors and chokes. The component chosen as a subject of this study is a magnetic inductor. There are several types of magnetic inductors, consequently HA00-XXX is selected for this study. It is because of it has stable production and the production is continuous throughout the year. Furthermore, this product is chosen because it represents various types of process in the production line.

The resources allocated are based on 4 groups: (i) labor costs, (ii) maintenance cost for the machinery (iii) raw materials costs and (iv) consumable material costs. The costs incurred are obtained from the production company which are detailed in the Table 1.

Table 1: Labor, maintenance, material and consumable cost for 13 workstations

\begin{tabular}{|c|c|c|c|c|c|c|}
\hline Activity & Sub-activities & $\begin{array}{l}\text { Labor } \\
(\mathrm{MYR})\end{array}$ & $\begin{array}{l}\text { Maintenance } \\
\text { (MYR) }\end{array}$ & $\begin{array}{l}\text { Material } \\
(\mathrm{MYR})\end{array}$ & $\begin{array}{l}\text { Consumable } \\
\text { (MYR) }\end{array}$ & $\begin{array}{l}\text { Cost of all } \\
\text { resources } \\
\text { supplied } \\
\text { (MYR) }\end{array}$ \\
\hline 1. Winding & $\begin{array}{l}\text { 1. The wire are winded } \\
\text { using CNC machine }\end{array}$ & 24,000 & $26,449.89$ & 576,000 & nil & $626,449.89$ \\
\hline \multirow[t]{2}{*}{ 2. Flattening } & $\begin{array}{l}\text { 2. Pick up the coils from } \\
\text { winding station }\end{array}$ & 12,000 & nil & nil & nil & 12,000 \\
\hline & $\begin{array}{l}\text { 3. Flatten the coils by using } \\
\text { hydraulic press machines }\end{array}$ & 36,000 & 70 & nil & 144 & 36,214 \\
\hline \multirow[t]{2}{*}{ 3. Trimming } & $\begin{array}{l}\text { 4. Pick up the coils from } \\
\text { flattening station }\end{array}$ & 12,000 & nil & nil & nil & 12,000 \\
\hline & $\begin{array}{l}\text { 5. Trim the coils by using } \\
\text { pneumatic press machines }\end{array}$ & 36,000 & nil & nil & 192 & 36,192 \\
\hline 4. Forming & $\begin{array}{l}\text { 6. Bend the coils by using } \\
\text { pneumatic press machines }\end{array}$ & 48,000 & nil & nil & 192 & 48,192 \\
\hline \multirow[t]{2}{*}{ 5. Soldering } & 7. Dip the coils into flux & 12,000 & nil & nil & 12,960 & 24,960 \\
\hline & 8. Dip the coils into solder & 12,000 & nil & nil & $445,064.32$ & $457,064.32$ \\
\hline \multirow[t]{2}{*}{$\begin{array}{l}\text { 6. Epoxy } \\
\text { application }\end{array}$} & $\begin{array}{l}\text { 9. Arrange core on the } \\
\text { magnetic strip }\end{array}$ & 12,000 & nil & $1,440,000$ & nil & $1,452,000$ \\
\hline & $\begin{array}{l}\text { 10. Put the magnetic strip } \\
\text { into the epoxy machine. }\end{array}$ & 12,000 & nil & $\overline{\text { nil }}$ & $201,600.00$ & 213,600 \\
\hline 7. Assembly 1 & $\begin{array}{l}\text { 11. Assemble coil to the I- } \\
\text { core. }\end{array}$ & 72,000 & nil & 480,000 & 403.2 & $552,403.2$ \\
\hline 8. Assembly 2 & $\begin{array}{l}\text { 12. Assemble core with I- } \\
\text { core. }\end{array}$ & 48,000 & nil & nil & 268.8 & $48,268.8$ \\
\hline $\begin{array}{l}\text { 9. Oven } \\
\text { Curing }\end{array}$ & $\begin{array}{l}\text { 13. Put the inductor into } \\
\text { oven }\end{array}$ & 24,000 & nil & nil & 24 & 24,024 \\
\hline $\begin{array}{l}\text { 10. Boundary } \\
\text { inspection }\end{array}$ & $\begin{array}{l}\text { 14. The inductors undergo } \\
\text { boundary inspection }\end{array}$ & 24,000 & nil & nil & 134.4 & $24,134.4$ \\
\hline $\begin{array}{l}11 . \text { Laser } \\
\text { marking }\end{array}$ & $\begin{array}{l}15 . \text { Put the inductors into } \\
\text { laser marking machine }\end{array}$ & 24,000 & 626.53 & nil & nil & $24,626.53$ \\
\hline $\begin{array}{l}\text { 12. Co- } \\
\text { planarity and } \\
\text { VMI test }\end{array}$ & $\begin{array}{l}\text { 16. Inspect inductors for co- } \\
\text { planarity and then into VMI } \\
\text { equipment. }\end{array}$ & 24,000 & nil & nil & 130,824 & $154,824.00$ \\
\hline 13. Packaging & 17. Pack inductors & 24,000 & nil & nil & $24,384.00$ & $48,384.00$ \\
\hline Total & & 456,000 & $27,146.42$ & $2,496,000$ & $803,230.72$ & $3,782,377.14$ \\
\hline
\end{tabular}


The factory's working hours are from Monday to Friday, 8 a.m. to 5.35 p.m. The operators work for 8 hours and 35 minutes per day, excluding 1 hour break daily, for 20 days a month. Each operator has an acceptable capacity of 10,300 minutes every month. Therefore, the practical capacity per year is 123,600 minutes for every operator. Capacity cost rate (CCR) for each activity and sub-activity is as portrayed in the Table 2. CCR is calculated using the formula in Equation (1) as shown below.

Capacity cost rate $=\frac{\text { Cost of all resources supplied }}{\text { Practical capacity }}$

Table 2: Capacity cost rate of each sub-activity

\begin{tabular}{|c|c|c|c|c|}
\hline Activity & Sub-activities & $\begin{array}{c}\text { Cost of all } \\
\text { resources } \\
\text { supplied }(\mathrm{MYR})\end{array}$ & $\begin{array}{l}\text { Practical } \\
\text { capacity } \\
(\min )\end{array}$ & $\begin{array}{l}\text { Capacity } \\
\text { cost rate } \\
(\mathrm{MYR})\end{array}$ \\
\hline 1. Winding & $\begin{array}{l}\text { 1. The wire are winded using } \mathrm{CNC} \\
\text { machine }\end{array}$ & $626,449.89$ & 247,200 & 2.53 \\
\hline \multirow[t]{2}{*}{ 2. Flattening } & 2. Pick up the coils from winding station & 12,000 & 123,600 & 0.10 \\
\hline & $\begin{array}{l}\text { 3. Flatten the coils by using hydraulic } \\
\text { press machines }\end{array}$ & 36,214 & 370,800 & 0.10 \\
\hline \multirow[t]{2}{*}{ 3. Trimming } & $\begin{array}{l}\text { 4. Pick up the coils from flattening } \\
\text { station }\end{array}$ & 12,000 & 123,600 & 0.10 \\
\hline & $\begin{array}{l}\text { 5. Trim the coils by using pneumatic } \\
\text { press machines }\end{array}$ & 36,192 & 370,800 & 0.10 \\
\hline 4. Forming & $\begin{array}{l}6 \text {. Bend the coils by using pneumatic } \\
\text { press machines }\end{array}$ & 48,192 & 494,400 & 0.10 \\
\hline \multirow[t]{2}{*}{ 5. Soldering } & 7. Dip the coils into flux & 24,960 & 123,600 & 0.20 \\
\hline & 8. Dip the coils into solder & $457,064.32$ & 123,600 & 3.70 \\
\hline \multirow{2}{*}{$\begin{array}{l}\text { 6. Epoxy } \\
\text { application }\end{array}$} & 9. Arrange core on the magnetic strip & $1,452,000$ & 123,600 & 11.75 \\
\hline & $\begin{array}{l}\text { 10. Put the magnetic strip into the epoxy } \\
\text { machine. }\end{array}$ & 213,600 & 123,600 & 1.73 \\
\hline 7. Assembly 1 & 11. Assemble coil to the I-core. & $552,403.20$ & 741,600 & 0.74 \\
\hline 8. Assembly 2 & 12. Assemble core with I-core. & $48,268.80$ & 494,400 & 0.10 \\
\hline 9. Oven curing & 13. Put the inductor into oven & 24,024 & 247,200 & 0.10 \\
\hline $\begin{array}{l}\text { 10. Boundary } \\
\text { inspection }\end{array}$ & $\begin{array}{l}\text { 14. The inductors undergo boundary } \\
\text { inspection }\end{array}$ & $24,134.40$ & 247,200 & 0.10 \\
\hline $\begin{array}{l}\text { 11. Laser } \\
\text { marking }\end{array}$ & $\begin{array}{l}\text { 15. Put the inductors into laser marking } \\
\text { machine }\end{array}$ & $24,626.53$ & 247,200 & 0.10 \\
\hline $\begin{array}{l}\text { 12. Co-planarity } \\
\text { and VMI test }\end{array}$ & $\begin{array}{l}\text { 16. Inspect inductors for co-planarity } \\
\text { and then into VMI equipment. }\end{array}$ & $154,824.00$ & 247,200 & 0.63 \\
\hline \multirow[t]{2}{*}{ 13. Packaging } & 17. Pack inductors & $48,384.00$ & 247,200 & 0.20 \\
\hline & & Total & $4,696,800$ & \\
\hline
\end{tabular}

A time equation must be developed in order to determine the expected production time. By monitoring and interviewing operators performing their activities in production line, the average duration for every operation was obtained. For an example when using CNC machines in the endorsement factory, the average time needed for the wire to be a wind is 0.12 minutes. This number is multiplied by the corresponding time function factors or cost drivers. Table 3 describes every variable in the time equation. The time equation is formulated by using TDABC time as shown in Equation (2) below.

$\mathrm{T}_{\mathrm{t}}=\beta_{\mathrm{o}}+\beta_{\mathrm{i}} \mathrm{X}_{\mathrm{i}}$

Where:

$\mathrm{T}_{\mathrm{t}}=$ the time needed to perform an activity (minute).

$\beta_{\mathrm{o}}=$ the standard time to perform the basic activity (minute). 
$\beta_{\mathrm{i}}=$ the estimated time to perform the incremental activity (minute).

$\mathrm{X}_{\mathrm{i}}=$ the volume of the incremental activity (time).

Table 3: Time equations for all sub-activities

\begin{tabular}{llr}
\hline \multicolumn{1}{c}{ Activity } & \multicolumn{1}{c}{ Sub-activities } & Time equations \\
\hline 1.Winding & 1. The wire are winded using CNC machine & $0.12 \mathrm{X}_{1}$ \\
\hline 2.Flattening & 1. Pick up the coils from winding station & $10.00 \mathrm{X}_{2}$ \\
& 2.. Flatten the coils by using hydraulic press machines & $0.22 \mathrm{X}_{3}$ \\
\hline 3.Trimming & 1. Pick up the coils from flattening station & $10.00 \mathrm{X}_{4}$ \\
& 2. Trim the coils by using pneumatic press machines & $0.13 \mathrm{X}_{5}$ \\
\hline 4.Forming & 1. Bend the coils by using pneumatic press machines & $0.17 \mathrm{X}_{6}$ \\
\hline 5.Soldering & 1. Pick the coils using pliers and dip the coils into flux & $0.72 \mathrm{X}_{7}$ \\
& 2. Dip the coils into solder. & $0.18 \mathrm{X}_{8}$ \\
\hline 6.Epoxy application & 1. Arrange core on the magnetic strip. & $0.15 \mathrm{X}_{9}$ \\
& 2. Put the magnetic strip into the epoxy machine and run the & $2.7 \mathrm{X}_{10}$ \\
\hline 7.Assembly 1 & machine. & $0.07 \mathrm{X}_{11}$ \\
\hline 8.Assembly 2 & 1. Assemble coil to the I-core & $0.14 \mathrm{X}_{12}$ \\
\hline 9.Curing & 1. Put the inductor into oven & $40 \mathrm{X}_{13}$ \\
\hline 10.Boundary inspection & 1. The inductors undergo boundary inspection & $0.05 \mathrm{X}_{14}$ \\
\hline 11.Laser marking & 1. Put the inductors into laser marking machine & $0.05 \mathrm{X}_{15}$ \\
\hline 12.Co-planarity and VMI & 1. Inspect inductors for co-planarity and VMI & $0.52 \mathrm{X}_{16}$ \\
\hline 13.Packaging & 1. Pack inductors & $3.00 \mathrm{X}_{17}$ \\
\hline
\end{tabular}

From Table 3, the time equation for all the sub-activities was developed as shown in Equation (4) below.

$\mathrm{T}_{\text {sub-activities }}=0.12 \mathrm{X}_{1}+10.00 \mathrm{X}_{2}+0.22 \mathrm{X}_{3}+10.00 \mathrm{X}_{4}+0.13 \mathrm{X}_{5}+0.17 \mathrm{X}_{6}+0.72 \mathrm{X}_{7}+0.18 \mathrm{X}_{8}+0.15 \mathrm{X}_{9}+$

$2.7 \mathrm{X}_{10}+0.07 \mathrm{X}_{11}+0.14 \mathrm{X}_{12}+40 \mathrm{X}_{13}+0.05 \mathrm{X}_{14}+0.05 \mathrm{X}_{15}+0.52 \mathrm{X}_{16}+3.00 \mathrm{X}_{17}$

By quantifying the frequency of the activity in a month, the approximate capacity needed for each operation was measured. If the sum of an activity multiplied by the time it was spent, the total time spent on the activity could be evaluated. Table 4 summarizes the amounts of cost drivers for the wood preparation activity centre.

Table 4: Volume of cost drivers for the magnetic inductor

\begin{tabular}{|c|c|c|c|c|}
\hline Activity & Var. & Sub-activities & Driver & Quantity/year \\
\hline 1.Winding & $\mathrm{X}_{1}$ & $\begin{array}{l}\text { 1. The wire are winded using } \\
\text { CNC machine }\end{array}$ & Amount of raw material $(\mathrm{kg})$ & $8,697.6$ \\
\hline \multirow[t]{2}{*}{ 2.Flattening } & $\mathrm{X}_{2}$ & $\begin{array}{l}\text { 1. Pick up the coils from } \\
\text { winding station }\end{array}$ & $\begin{array}{l}\text { Pick up the coils from winding } \\
\text { station (rounds) }\end{array}$ & 480 \\
\hline & $\mathrm{X}_{3}$ & $\begin{array}{l}\text { 2. Flatten the coils by using } \\
\text { hydraulic press machines }\end{array}$ & $\begin{array}{l}\text { Number of hydraulic press machine } \\
\text { operating (frequency) }\end{array}$ & 960,000 \\
\hline \multirow[t]{2}{*}{ 3.Trimming } & $\mathrm{X}_{4}$ & $\begin{array}{l}\text { 1. Pick up the coils from } \\
\text { flattening station }\end{array}$ & $\begin{array}{l}\text { Pick up the coils from flattening } \\
\text { station (rounds) }\end{array}$ & 480 \\
\hline & $\mathrm{X}_{5}$ & $\begin{array}{l}\text { 2. Trim the coils by using } \\
\text { pneumatic press machines }\end{array}$ & $\begin{array}{l}\text { Number of pneumatic press } \\
\text { machine operating } \\
\text { (frequency/month) }\end{array}$ & $2,400,000$ \\
\hline 4.Forming & $\mathrm{X}_{6}$ & $\begin{array}{l}\text { 1. Bend the coils by using } \\
\text { pneumatic press machines }\end{array}$ & $\begin{array}{l}\text { Number of pneumatic press } \\
\text { machine operating } \\
\text { (frequency/month) }\end{array}$ & $2,400,000$ \\
\hline \multirow[t]{2}{*}{ 5.Soldering } & $\mathrm{X}_{7}$ & $\begin{array}{l}\text { 1. Pick the coils using pliers } \\
\text { and dip the coils into flux }\end{array}$ & Amount of flux used (litre) & 432 \\
\hline & $\mathrm{X}_{8}$ & 2. Dip the coils into solder. & Amount of solder used $(\mathrm{kg})$ & 2,400 \\
\hline
\end{tabular}




\begin{tabular}{|c|c|c|c|c|}
\hline \multirow[t]{2}{*}{$\begin{array}{l}\text { 6.Epoxy } \\
\text { application }\end{array}$} & $\mathrm{X}_{9}$ & $\begin{array}{l}\text { 1. Arrange core on the magnetic } \\
\text { strip. }\end{array}$ & $\begin{array}{l}\text { Arrange core on the magnetic strip } \\
\text { (amount of core) }\end{array}$ & $4,800,000$ \\
\hline & $\mathrm{X}_{10}$ & $\begin{array}{l}\text { 2. Put the magnetic strip into } \\
\text { the epoxy machine and run the } \\
\text { machine. }\end{array}$ & Amount of epoxy used (litre) & 201.6 \\
\hline 7.Assembly 1 & $\mathrm{X}_{11}$ & 1. Assemble coil to the I-core & Amount of material (quantity) & $4,800,000$ \\
\hline 8.Assembly 2 & $X_{12}$ & 1. Assemble core with I-core. & Amount of material (quantity) & $4,800,000$ \\
\hline 9. Oven curing & $\mathrm{X}_{13}$ & 1. Put the inductor into oven & Clipping process (frequency) & $4,800,000$ \\
\hline $\begin{array}{l}\text { 10.Boundary } \\
\text { inspection }\end{array}$ & $\mathrm{X}_{1}$ & $\begin{array}{l}\text { 1. The inductors undergo } \\
\text { boundary inspection }\end{array}$ & Product item (quantity) & $4,800,000$ \\
\hline $\begin{array}{l}\text { 11.Laser } \\
\text { marking }\end{array}$ & $\mathrm{X}_{15}$ & $\begin{array}{l}\text { 1. Put the inductors into laser } \\
\text { marking machine }\end{array}$ & Laser marking machine (frequency) & $4,800,000$ \\
\hline $\begin{array}{l}\text { 12.Co- } \\
\text { planarity and } \\
\text { VMI }\end{array}$ & $\mathrm{X}_{16}$ & $\begin{array}{l}\text { 1. Inspect inductors for co- } \\
\text { planarity and VMI }\end{array}$ & Inspection (frequency) & $4,800,000$ \\
\hline 13.Packaging & $\mathrm{X}_{17}$ & 1. Pack inductors & Product items (quantity) & $4,800,000$ \\
\hline
\end{tabular}

The actual time spent on this activity center per month was determined by substituting the volume of cost-drivers as shown in Equation (5) below.

The actual time spent $=(0.12 \times 8,697.6)+(10 \times 480)+(0.22 \times 960,000)+(10 \times 480)+(0.13 \times 2,400,000)+$ $(0.17 \times 2,400,000)+(0.72 \times 432)+(0.18 \times 2,400)+(0.15 \times 4,800,000)+(2.7 \times 201.6)+(0.07 \times 4,800,000)+$ $(0.14 \times 4,800,000)+(40 \times 4,800,000)+(0.05 \times 4,800,000)+(0.05 \times 4,800,000)+(0.52 \times 4,800,000)+$ $(3 \times 4,800,000)=212,047,131.07$ minutes

The last step for implementing TDABC method is to analyse the capacity utilization. Unused time can be obtained by subtracting the value of practical capacity with used time. Unused cost on the other hand, is obtained by multiplying unused time with capacity cost rate. For an example, the total time for the wire to be winded using CNC machine in one month can be represented by $\mathrm{X}_{1}$ equals $8,697.6$ in $0.12 \mathrm{X}_{1}$, so that $0.12 \times 8697.6=1043.71$ minutes. When multiplied by capacity cost rate of 2.53 , it can be determined that the total cost of this activity is RM 2,644.96. Based on the same approach, the total production cost for each workstation is shown in Table 5.

Table 5: Analysis of capacity utilization

\begin{tabular}{|c|c|c|c|c|c|c|}
\hline Activity & Sub-activities & $\begin{array}{l}\text { Practical } \\
\text { capacity }\end{array}$ & Used time (min) & $\begin{array}{l}\text { Total cost } \\
\text { (MYR) }\end{array}$ & Unused time $(\min )$ & $\begin{array}{l}\text { Unused cost } \\
\text { (MYR) }\end{array}$ \\
\hline Winding & $\begin{array}{l}\text { Wind wires } \\
\text { using CNC } \\
\text { machine }\end{array}$ & 218,400 & $1,043.71$ & $2,644.96$ & $246,156.29$ & $623,804.93$ \\
\hline \multirow[t]{2}{*}{ Flattening } & $\begin{array}{l}\text { Pick up the coils } \\
\text { from winding } \\
\text { station }\end{array}$ & 109,200 & $4,800.00$ & 466.02 & $118,800.00$ & $11,533.98$ \\
\hline & $\begin{array}{l}\text { Flatten the coils } \\
\text { by using } \\
\text { hydraulic press } \\
\text { machines }\end{array}$ & 327,600 & $211,200.00$ & $20,626.74$ & $159,600.00$ & $15,587.26$ \\
\hline \multirow[t]{2}{*}{ Trimming } & $\begin{array}{l}\text { Pick up the coils } \\
\text { from flattening } \\
\text { station }\end{array}$ & 109,200 & $4,800.00$ & 466.02 & $118,800.00$ & $11,533.98$ \\
\hline & $\begin{array}{l}\text { Trim the coils } \\
\text { by using } \\
\text { pneumatic press } \\
\text { machines }\end{array}$ & 327,600 & $312,000.00$ & $30,452.82$ & $58,800.00$ & $5,739.18$ \\
\hline Forming & $\begin{array}{l}\text { Bend the coils } \\
\text { by using } \\
\text { pneumatic press } \\
\text { machines }\end{array}$ & 436,800 & $408,000.00$ & $39,770.10$ & $86,400.00$ & $8,421.90$ \\
\hline
\end{tabular}




\begin{tabular}{|c|c|c|c|c|c|c|}
\hline \multirow[t]{2}{*}{ Soldering } & $\begin{array}{l}\text { Pick the coils } \\
\text { using pliers and } \\
\text { dip the coils into } \\
\text { flux }\end{array}$ & 109,200 & 311.04 & 62.81 & $123,288.96$ & $24,897.19$ \\
\hline & $\begin{array}{l}\text { Dip the coils } \\
\text { into solder }\end{array}$ & 109,200 & 432.00 & $1,597.51$ & $123,168.00$ & $455,466.81$ \\
\hline \multirow[t]{2}{*}{$\begin{array}{l}\text { Epoxy } \\
\text { application }\end{array}$} & $\begin{array}{l}\text { Arrange core on } \\
\text { the magnetic } \\
\text { strip }\end{array}$ & 109,200 & $720,000.00$ & $8,458,252.43$ & $-596,400.00$ & $-7,006,252.43$ \\
\hline & $\begin{array}{l}\text { Put the magnetic } \\
\text { strip into the } \\
\text { epoxy machine } \\
\text { and run the } \\
\text { machine }\end{array}$ & 109,200 & 544.32 & 940.67 & $123,055.68$ & $212,659.33$ \\
\hline Assembly 1 & $\begin{array}{l}\text { Assemble coil to } \\
\text { the I-core }\end{array}$ & 655,200 & $336,000.00$ & $250,279.77$ & $405,600.00$ & $302,123.43$ \\
\hline Assembly 2 & $\begin{array}{l}\text { Assemble core } \\
\text { with I-core }\end{array}$ & 436,800 & $672,000.00$ & $65,608.08$ & $-177,600.00$ & $-17,339.28$ \\
\hline Oven curing & $\begin{array}{l}\text { Put the inductor } \\
\text { into oven }\end{array}$ & 218,400 & $192,000,000.00$ & $18,659,417.48$ & $-191,752,800.00$ & $-18,635,393.48$ \\
\hline $\begin{array}{l}\text { Boundary } \\
\text { inspection }\end{array}$ & $\begin{array}{l}\text { The inductors } \\
\text { undergo } \\
\text { boundary } \\
\text { inspection }\end{array}$ & 218,400 & $240,000.00$ & $23,431.46$ & $7,200.00$ & 702.94 \\
\hline $\begin{array}{l}\text { Laser } \\
\text { marking }\end{array}$ & $\begin{array}{l}\text { Put the } \\
\text { inductors into } \\
\text { laser marking } \\
\text { machine }\end{array}$ & 218,400 & $240,000.00$ & $23,909.25$ & $7,200.00$ & 717.28 \\
\hline $\begin{array}{l}\text { Co-planarity } \\
\text { and VMI }\end{array}$ & $\begin{array}{l}\text { Inspect } \\
\text { inductors for co- } \\
\text { planarity and } \\
\text { VMI }\end{array}$ & 218,400 & $2,496,000.00$ & $1,563,271.46$ & $-2,248,800.00$ & $-1,408,447.46$ \\
\hline Packaging & Pack inductors & 218,400 & $14,400,000.00$ & $2,818,485.44$ & $-14,152,800.00$ & $-2,770,101.44$ \\
\hline Total & & $4,696,800$ & $212,047,131.07$ & $31,959,682.99$ & $-207,350,331.07$ & $-28,164,345.85$ \\
\hline
\end{tabular}

Figure 2 demonstrates a bar chart of total and unused capacity for both duration (minute) and cost (MYR) for sub-activity 1; the wires are winded using CNC machine. In terms of duration, there are two bars; light yellow bar indicates the total time allocated for the sub-activity which is the practical capacity, dark yellow bar indicates the unused capacity of the sub-activity. In terms of cost, the dark green bar indicates the total cost allocated while the light green bar indicates the unused cost capacity of the sub-activity. Based on the chart, the total time allocated is 218,400 minutes and the unused time is $246,156.29$ minutes. In order to overcome this, the job scope of this workstation or this sub-activity needs to be re-examined so that maximum time for productivity can be achieved by fully utilizing the allocated time. On the other hand, the total cost allocated is MYR 626,449.89 and the unused capacity cost is MYR 623,804.93. This conveys the message of wastage at the workstation.

Figure 3 shows a comparison of total and unused capacity for duration and capacity cost of subactivity 3; pick up the coils from flattening station. In terms of duration, there are two bars; light yellow bar indicates the total time allocated for the sub-activity which is the practical capacity, dark yellow bar indicates the unused capacity of the sub-activity. In terms of cost, the light green bar indicates the total cost allocated while the dark green bar indicates the unused cost capacity of the sub-activity. The chart shows the total of time assigned to the sub-activity that is 370,800 minutes and has unused amount of 159,600 minutes. A total cost of MYR 36,214 is assigned and has an amount of MYR 15,587.26 is unused. The unused time shows that there is unused amount of time for productivity. In order to overcome this, consider to relocate the operators' workstation according to amount of work. 


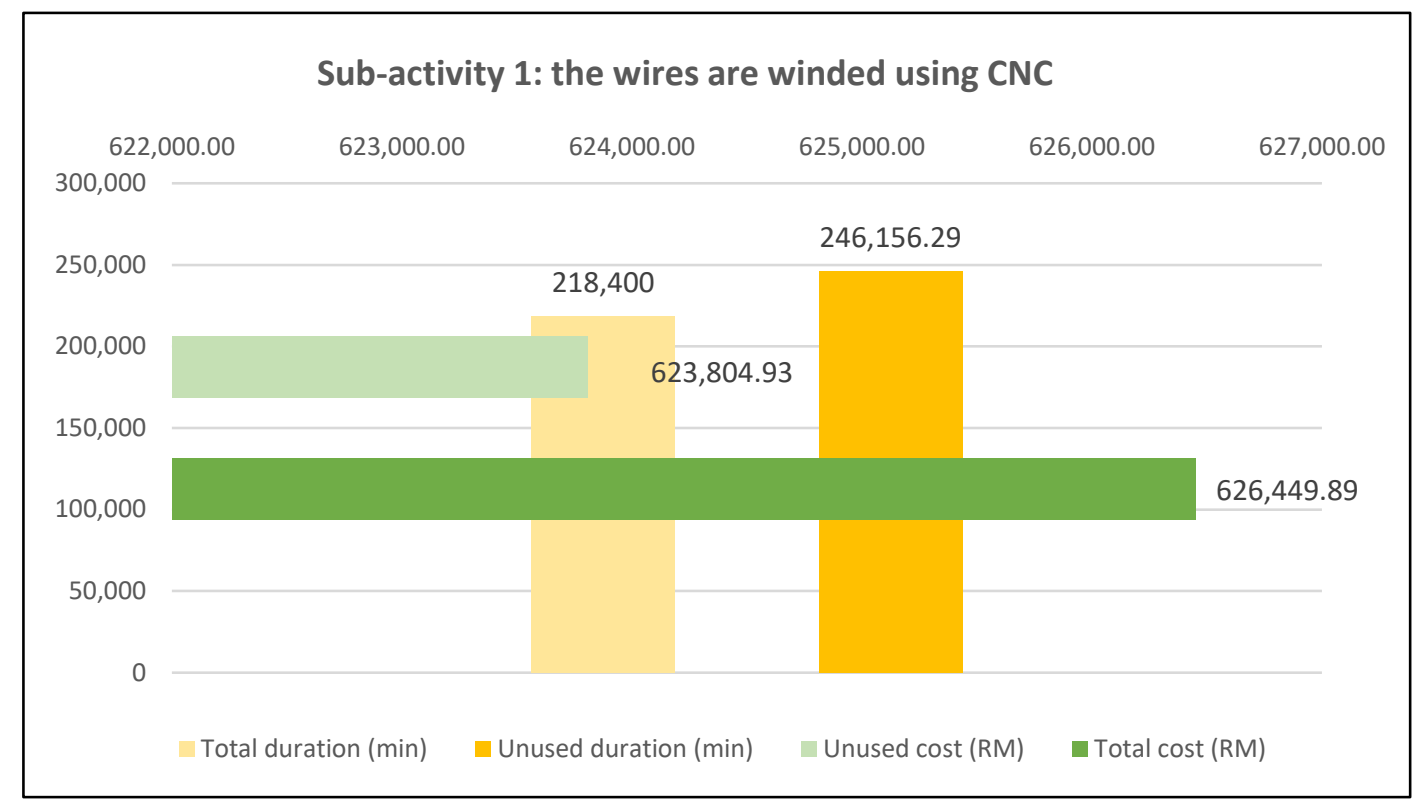

Figure 2: Analysis of sub-activity 1

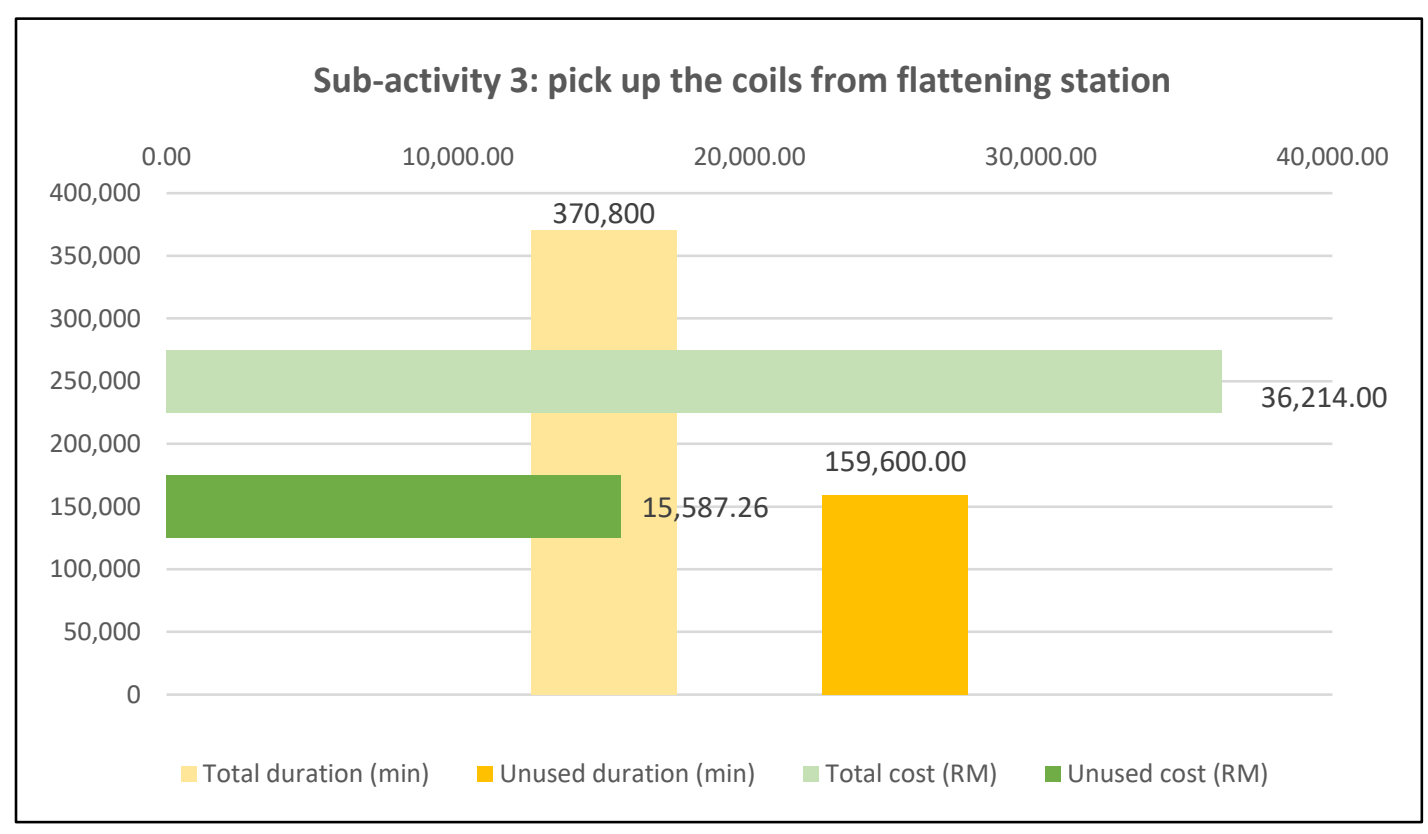

Figure 3: Analysis of sub-activity 3

Figure 4 shows a comparison of total and unused capacity for duration and capacity cost of subactivity 9; arrange core on the magnetic strip. In terms of duration, there are two bars; light yellow bar indicates the total time allocated for the sub-activity which is the practical capacity, dark yellow bar indicates the unused capacity of the sub-activity. In terms of cost, the light green bar indicates the total cost allocated while the dark green bar indicates the unused cost capacity of the sub-activity. The chart shows the total of time assigned to the sub-activity that is 123,600 minutes and has unused amount of 596,400 minutes. A total cost of MYR 1,452,000 is assigned and has an amount of MYR -7,006,252.43 are unused. The negative value of both unused capacity in terms of time and cost demonstrate that the capacities are highly insufficient. This would cause for the operators to overworked in order to achieve the targeted demand. The job scopes are probably taking more time than it should to be completed. 


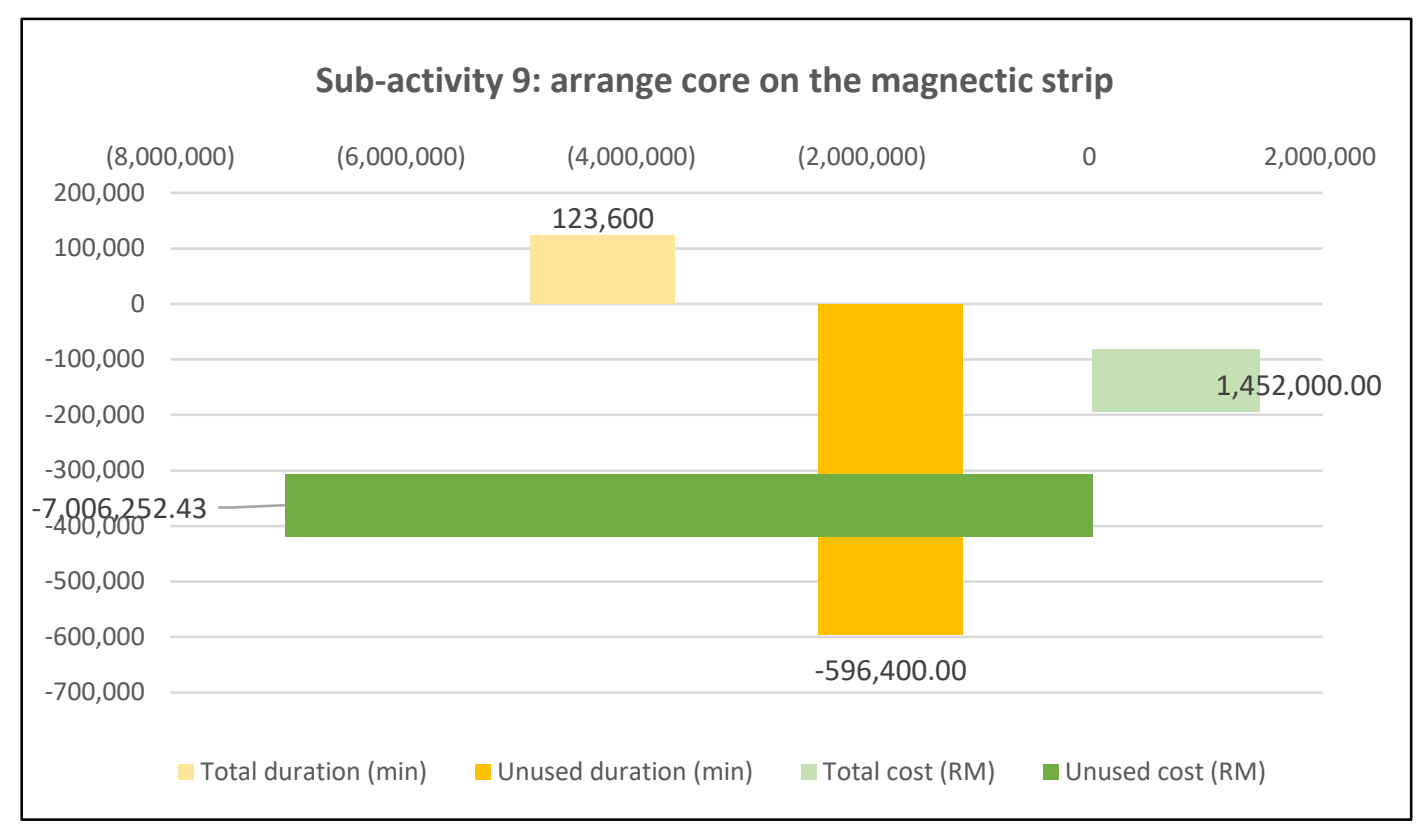

Figure 4: Analysis of sub-activity 9

\section{CONCLUSION}

This work has implemented process of time-driven activity-based costing in an electrical and electronics production company on a specific production line of a magnetic inductor to determine the unused capacity in term of duration and cost. Time equation and CCR can act as a tool for the manager to assess the unused capacity. From the value of unused capacity means the manager can reduce the resources for better saving. As a result, in sub-activity-1 of the wire are winded using CNC machine, the unused time was $246,156.29$ minutes which needs to be re-examined so that maximum time for productivity can be achieved and the unused capacity of cost was MYR 623,804.93 which conveys the message of wastage at the workstation. In sub-activity- 3 of pick up the coils from flattening station, the amount of unused time and cost was $-596,400$ minutes and MYR -7,006,252.43 respectively. The negative value demonstrated that the operators are overworked than normal time allocation. In sub-activity 9 of arrange core on the magnetic strip, the amount of unused time was $-596,400$ minutes and MYR -7,006,252.43 for unused cost probably the job scopes were taking more time than it should to be completed. Therefore, the manager has a clear view to reduce production costs based on the analysis of capacity utilization in order to increase working capacity and decrease unused costs.

\section{ACKNOWLEDGEMENT}

The authors would like to thank the Universiti Malaysia Pahang and Ministry of Education Malaysia for financial assistance under Research Grant project No. PGRS2003150.

\section{REFERENCES}

[1] Barros R.S., \& Costa Ferreira A.M.D.S. "Time-driven activity-based costing: designing a model in a Portuguese production environment", Qualitative Research in Accounting \& Management, 14(1), 2-20, 2017.

[2] Nik Mohd Kamil N.N., Abu M.Y., Zamrud N.F., \& Safeiee F.L.M. "Analysis of magnetic component manufacturing cost through the application of time-driven activity-based costing", 
Proceedings of the International Manufacturing Engineering Conference \& The Asia Pacific Conference on Manufacturing Systems 2019, 74-80, 2020.

[3] Dyk J.V., Zubizarreta E. \& Lievens Y. "Cost evaluation to optimize radiation therapy implementation in different income settings: a time-driven activity-based analysis", Radiotherapy and Oncology, 125, 178-185, 2017.

[4] Nowak C. \& Linder C. "Do you know how much your expatriate costs? An activity based cost analysis of expatriation", Journal of Global Mobility, 4(1), 88-107, 2016.

[5] Mohd Safeiee F.L., Abu M.Y., Nik Mohd Kamil N.N., \& Zamrud N.F. "The application of timedriven activity based costing system on inductors in electrics and electronics industry", Proceedings of the International Manufacturing Engineering Conference \& The Asia Pacific Conference on Manufacturing Systems 2019, 88-95, 2020.

[6] Nik Mohd Kamil N.N., \& Abu M.Y. "Integration of Mahalanobis-Taguchi System and activity based costing for remanufacturing decision", Journal of Modern Manufacturing Systems and Technology, 1, 39-51, 2018.

[7] Martino M., Console G., Russo L., Meliado A., Meliambro N., Moscato T., Irrera G., Messina G., Pontari A. \& Morabito F. "Autologous stem cell transplantation in patients with multiple myeloma: An activity-based costing analysis, comparing a total inpatient model versus an early discharge model”, Clinical Lymphoma, Myeloma \& Leukemia, 17(8), 506-512, 2017.

[8] Balakrishnan K., Goico B. \& Arjmand E.M. "Applying cost accounting to operating room staffing in otolaryngology: time-driven activity-based costing and outpatient adenotonsillectomy", Otolaryngology-Head and Neck Surgery, 152(4), 684-690, 2015.

[9] Waters P.M. "Value in pediatric orthopaedic surgery health care: the role of time-driven activitybased cost accounting (TDABC) and standardized clinical assessment and management plans (SCAMPs)", J Pediatr Orthop, 35, 45-47, 2015.

[10] Chang C. T., Chou Y.Y. \& Zhuang Z.Y. "A practical expected value-approach model to assess the relevant procurement costs", Journal of the Operational Research Society, 66(4), 539-553, 2015.

[11] Zheng C.W. \& Abu M.Y. "Application of activity based costing for palm oil plantation”, Journal of Modern Manufacturing Systems and Technology, 2, 1-14, 2019.

[12] Abu M.Y., Mohd Nor E.E. \& Abd Rahman M.S. "Costing improvement of remanufacturing crankshaft by integrating Mahalanobis-Taguchi System and Activity based Costing", IOP Conference Series: Materials Science and Engineering, 342, 1-10, 2018.

[13] Abu M.Y., Jamaludin K.R., \& Zakaria M.A. "Characterisation of activity based costing on remanufacturing crankshaft", International Journal of Automotive and Mechanical Engineering, 14(2), 4211-4224, 2017.

[14] Da Silva Medeiros H., Santana A. F. B. \& Da Silva Guimarães L. "The use of costing methods in Lean Manufacturing industries: A literature review”, Gestao e Producao, 24(2), 395-406, 2017.

[15] Pongwasit R. \& Chompu-inwai R. "Analysis of wooden toy manufacturing costs through the application of a time-driven activity-based costing system", Memoirs of The Muroran Institute of Technology, 65, 7-14, 2015.

[16] Zhuang Z.Y. \& Chang S.C. "Deciding product mix based on time-driven activity-based costing by mixed integer programming", Journal of Intelligent Manufacturing, 28(4), 959-974, 2017.

[17] Bauer-Nilsen K., Hill C., Trifiletti D.M., Libby B., Lash D.H., Lain M., Christodoulou D., Hodge C. \& Showalter T.N. "Evaluation of delivery costs for external beam radiation therapy and brachytherapy for locally advanced cervical cancer using time-driven activity-based costing", International Journal of Radiation Oncology Biology Physics, 100(1), 88-94, 2018.

[18] Keel G., Savage C., Rafiq M. \& Mazzocato P. "Time-driven activity-based costing in health care: A systematic review of the literature", Health Policy, 121(7), 755-763, 2017.

[19] Yu Y.R., Abbas P.I., Smith C.M., Carberry K.E., Ren H., Patel B., Nuchtern J.G. \& Lopez M.E. "Time-driven activity-based costing: A dynamic value assessment model in pediatric appendicitis", Journal of Pediatric Surgery, 52(6), 1045-1049, 2017. 
[20] Kaplan R.S. \& Haas D. "Defining, measuring, and improving value in spine care", Seminars in Spine Surgery, 30(2), 80-83, 2018.

[21] Beriwal S. \& Chino J. "Time-Driven Activity-Based Costing in Oncology: A Step in the Right Direction", International Journal of Radiation Oncology Biology Physics, 100(1), 95-96, 2018.

[22] Andreasen S.E., Holm H.B., Jørgensen M., Gromov K., Kjærsgaard-Andersen P. \& Husted H. "Time-driven Activity-based Cost of Fast-Track Total Hip and Knee Arthroplasty", Journal of Arthroplasty, 32(6), 1747-1755, 2017).

[23] Goense L., van Dijk W.A., Govaert J.A., van Rossum, P.S.N., Ruurda J.P. \& van Hillegersberg R. "Hospital costs of complications after esophagectomy for cancer", European Journal of Surgical Oncology, 43(4), 696-702, 2017.

[24] van der Linden Y.T.K., Govaert J.A., Fiocco M., van Dijk W.A., Lips D.J. \& Prins H.A. “Single center cost analysis of single-port and conventional laparoscopic surgical treatment in colorectal malignant diseases", International Journal of Colorectal Disease, 32(2), 233-239, 2017.

[25] Anzai Y., Heilbrun M.E., Haas D., Boi L., Moshre K., Minoshima S., Kaplan R. \& Lee V.S. "Dissecting Costs of CT Study: Application of TDABC (Time-driven Activity-based Costing) in a Tertiary Academic Center", Academic Radiology, 24(2), 200-208, 2017. 